\title{
PENERAPAN TEKNOLOGI VIRTUAL REALITY PHOTOGRAPHY PADA SISTEM INFORMASI OBJEK WISATA
}

\author{
Pacu Putra ${ }^{1}$, Mgs. Afriyan Firdaus ${ }^{2}$, Muhammad Farhan ${ }^{3}$ \\ ${ }^{123}$ Fakultas Ilmu Komputer, Universitas Sriwijaya \\ Ipacu89@gmail.com, 2afriyanfirdaus@gmail.com, ${ }^{3}$ muhammadfarhan280296@gmail.com
}

\begin{abstract}
Abstrak - Penerapan Teknologi Virtual Reality Photography pada sistem informasi objek wisata merupakan suatu langkah dalam memberikan pengalaman baru bagi seorang wisatawan dalam menjelajahi objek wisata secara visual $360^{\circ}$. Virtual Reality Photography memberikan sebuah tampilan visual yang berbeda daripada suatu sudut pandang gambar. Dengan adanya Virtual Reality Photography yaitu realitas maya buatan diharapkan wisatawan dapat menikmati dan merasakan pengalaman berjelajah yang baru.
\end{abstract}

Keywords — wisata, virtual reality, photography

\section{PENDAHULUAN}

Penerapan Teknologi Virtual Reality Photography telah memudahkan wisatawan dalam menjelajahi suatu objek wisata dalam realitas maya sehingga wisatawan dapat merasakan sebuah pengalaman berjejalah secara visual. Teknik Virtual Reality Photography juga disebut immersive photography atau photo panorama $360 \mathrm{o}$ adalah teknik fotografi untuk menampilkan foto suatu lokasi secara berkelanjutan (continously), tidak terpotong (seamless) dan tanpa tepi (borderless) dalam sudut pandang $360^{\circ} \mathrm{ke}$ arah horizontal dan atau vertikal .

Virtual Reality Photography saat ini sedang berkembang pesat dan telah menjadi teknologi visual yang populer,karena Virtual Reality Photography dapat memberikan pengalaman baru bagi user dengan menampilkan sudut pandang yang berbeda dalam melihat foto panorama .Virtual Reality Photography dapat memberikan user keadaan yang interaktif.

Virtual Reality Photograhy pada dasarnya memberikan pandangan seakan-akan user berada di dalam gambar atau lokasi yang diabadikan oleh fotografer. Gambar yang dihasilkan diberikan efek dengan menggunakan komputer, dimana hasil akhirnya disebut dengan VR Panorama. VR Panorama dapat dilihat dengan menggunakan aplikasi user interface yang interaktif. Hasilnya dapat di-klik dan diputar secara horizontal maupun vertikal menurut keinginan user, sehingga seakan-akan berada dalam pandangan lingkungan yang sebenarnya.[1]

Kebutuhan sebuah objek wisata dalam menarik perhatian seorang wisatawan menjadi suatu hal yang harus diperhatian. Bagaimana sektor wisata menjadi salah satu aspek penting dalam kemajuan sebuah daerah untuk terus berkembang. Hal inilah yang menjadi alasan dibutuhkanya suatu alat dalam mempromosikan sebuah objek wisata agar informasi tentang objek wisata yang dihararapkan dapat diterima oleh wisatawan.

\section{LANDASAN TEORI}

\section{A. Virtual Reality}

Virtual reality adalah lingkungan tiruan yang diciptakan dengan perangkat keras dan perangkat lunak computer dan disajikan kepada pemakai sehingga pemakai tersebut merasakan seperti di dalam lingkungan nyata Saat berada dalam virtual reality, pengguna akan merasa melebur seolah menyatu dengan dunianya, dan bisa berinteraksi dengan objekobjek yang ada di sana, dan hal ini disebut dengan telepresence.

\section{B. Virtual Reality Photography}

Virtual Reality Photgraphy adalah sebuah teknik yang memungkinkan pengguna untuk melihat secara interaktif dan real dari sebuah foto panorama sudut 360 deerajat. Virtual Reality Photography secara garis besar merupakan sebuah foto lebar yang memberikan pandangan visual 360 derajat dan menyanjikan pemandangan secara spherical kepada pengguna.[2]

Virtual Reality Photography merupakan sebuah teknik dalam menghasilkan sebuah foto $360^{\circ}$. Pada bagian ini akan dijelaskan tahapan tahapan yang ada pada pembuatan Virtual Reality Photography.[4]

Apabila kita berada di pusat daripada sebuah bola, dan melihat sekitar kita, semacam itulah kira-kira posisi seorang pengguna Virtual Reality Photography. Foto ini mampu menyajikan tour secara virtual dengan suasana yang sangat realistis dari lingkungannya. Virtual Reality Photgraphy adalah sebuah karya seni dalam merekam objek menyeluruh dari sebuah objek/lingkungan dalam sebuah foto yang di rekam. Foto ini dibuat dengan cara menggabungkan beberapa foto yang direkam dalam beberapa deretan foto yang mencakup pemandangan 360 derajat. Selanjutnya, foto-foto tersebut digabungkan dengan bantuan software yang dapat membantu foto tersebut terbentuk . Adapun manfaat Virtual Reality Photography ini dalam menyajikan tour secara virtual ini banyak dimanfaatkan perusahaan properti untuk menyajikan gambar secara interaktif kepada calon konsumennya. Biasanya gambar ini mereka 
presentasikan dalam sebuah media informasi, sehingga pengguna dapat melihat secara interaktif lingkungan yang diambil, baik itu sebuah kamar, objek wisata, kamar mandi, atau yang lainya.[3]

\section{METODE PENELITIAN}

Dalam penelitian ini, metode yang akan digunakan dalam penerapan teknologi Virtual Reality Photography Objek Wisata pada Dinas Pariwisata adalah metode Waterfall, yang terdiri dari: perencanaan, analisis, perancangan, penerapan, dan pengujian sistem [5].

Pada fase analisis, penulis melakukan analisis permasalahan terhadap objek wisata, penulis melakukan wawancara dan observasi ke dinas pariwisata dan beberapa objek wisata.

Pada fase perancangan, penulis merancang dengan menggunakan Contextual Diagram, Data Flow Diagram, dan, Entity Relationship Diagram.

Berikut pada gambar 1 dibawah ini merupakan salah satu Data Flow Diagram dari hasil rancangan sistem informasi objek wisata.

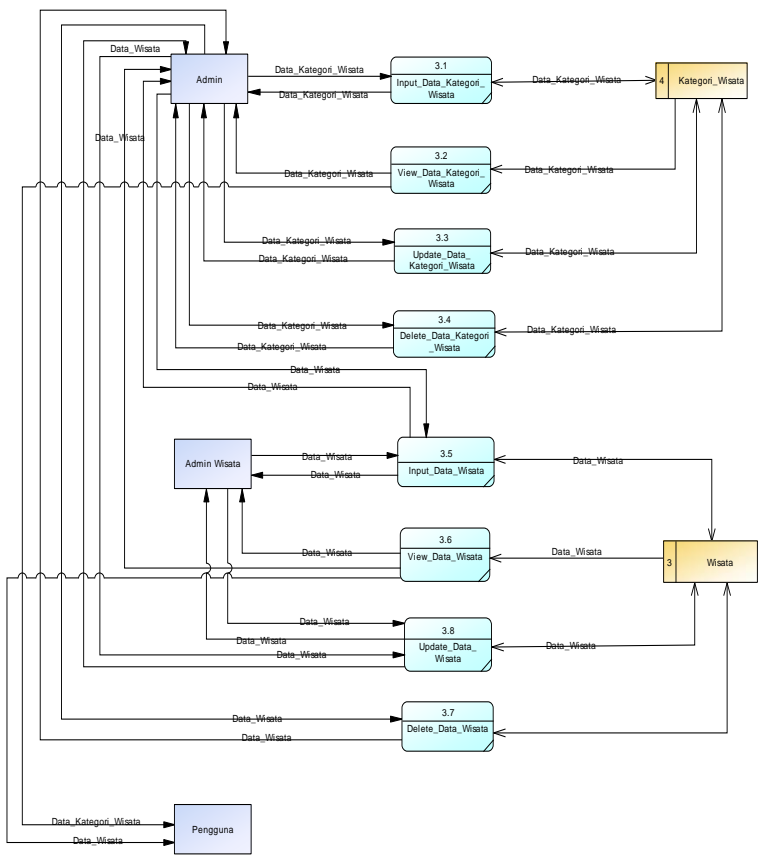

Gbr 1. Data Flow Diagram dari hasil rancangan sistem informasi objek wisata

Pada Gambar 2 berikut, ditunjukkan skema rancangan database pada system informasi objek wisata.

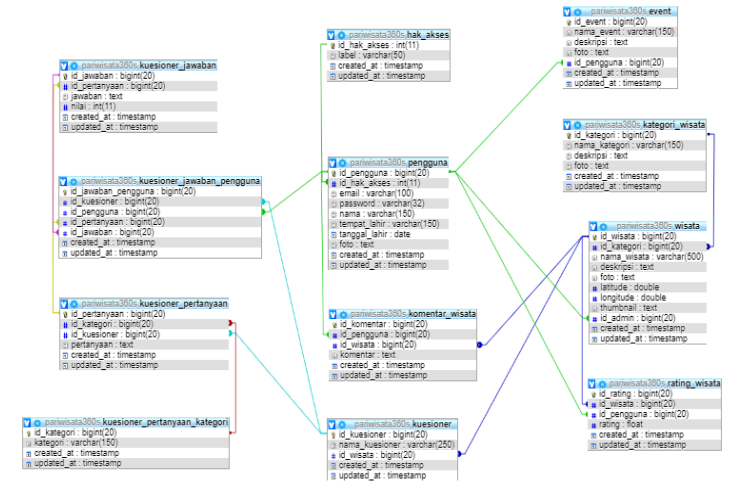

Gbr 2. Skema rancangan database pada system informasi objek wisata.

Pada gambar 3 dibawah ini tunjukkan arsitektur dari system informasi objek wisata, dimana dapat dilihat objek photography didalam sistem ini diambil menggunakan 360 camera, kemudian melalui proses Virtual reality geography yang nantinya dapat di akses oleh pengguna baik menggunakan telepon genggam ataupun computer melalui internet

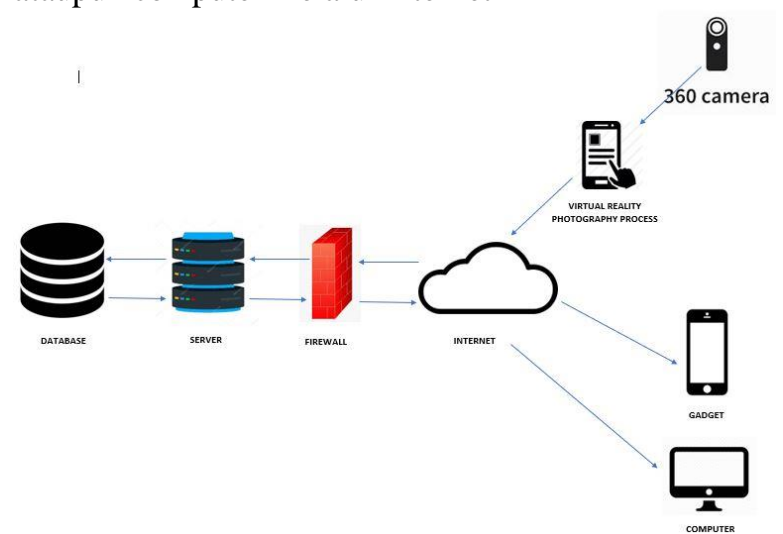

Gbr 3. Arsitektur dari system informasi objek wisata

Pada fase penerapan, penulis menerapkann hasil perancangan yang telah dibuat dengan menggunakan Bahasa PHP dan HTML.

Pada fase pengujian, penulis melakukan pengujian blackbox, dan melakukan uji coba kepada beberapa pengunjung objek wisata.

Didalam fase penerapan, penulis melakukan pengambilan data foto 360 guna untuk membuat Virtual reality Photography,adapun langkah-langkah pembuatan Virtual Reality Photography dari awal sampai dengan menghasilkan produk Virtual Reality Photography dalam bentuk format jpeg $360^{\circ}$ derajat. 


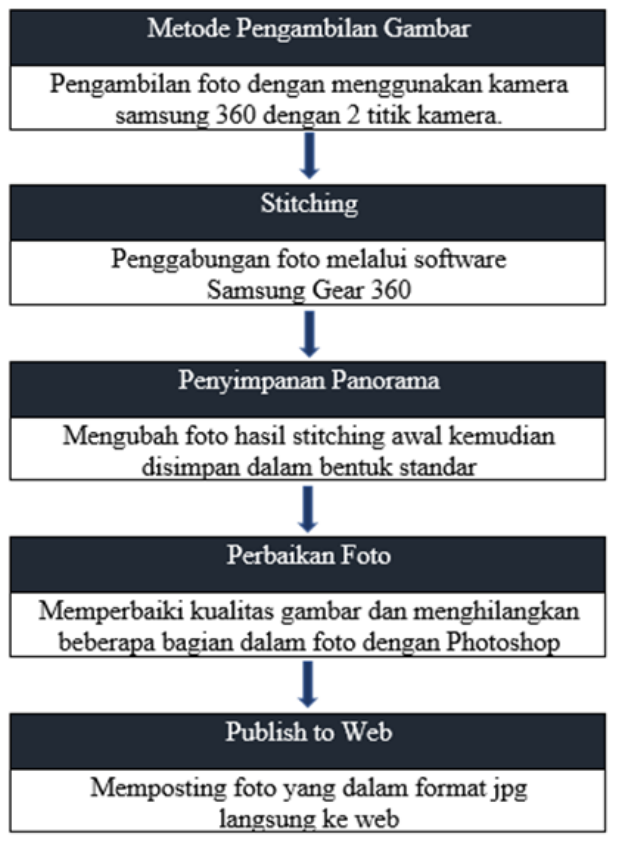

Gbr 4. Tahap pembuatan virtual reality photography

\section{IV.HASIL DAN PEMBAHASAN}

Berikut merupakan hasil dari penerapan teknologi virtual reality photography pada sistem informasi objek wisata.

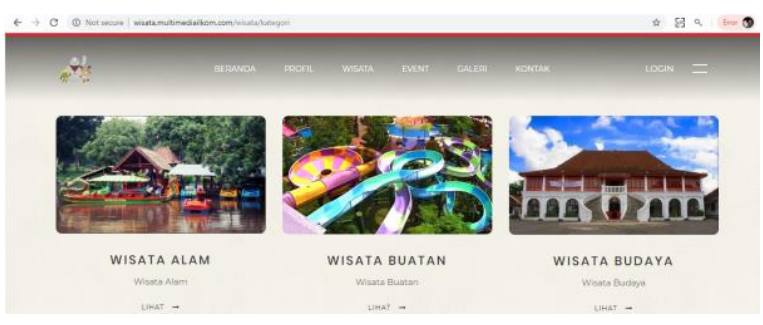

Gbr 5. Halaman utama penerapan teknologi virtual reality photography

Pada gambar 5 merupakan halaman utama pada sistem informasi objek wisata yang telah diterapkan virtual reality photography. Pengunjung sistem informasi objek wisata akan mendapatkan tampilan seperti gambar 6 setelah memilih objek wisata yang ingin dilihat.

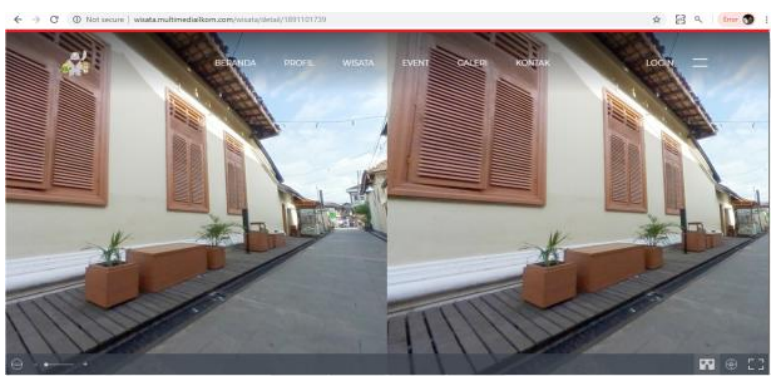

Gbr 6. Sensasi reality melalui telepon genggam atau gadget pengguna
Pada saat tampilan sistem informasi seperti pada gambar 6, pengguna dapat menggunakan VRBox guna untuk mendapatkan sensasi reality didalam dunia virtual melalui telepon genggam atau gadget pengguna.

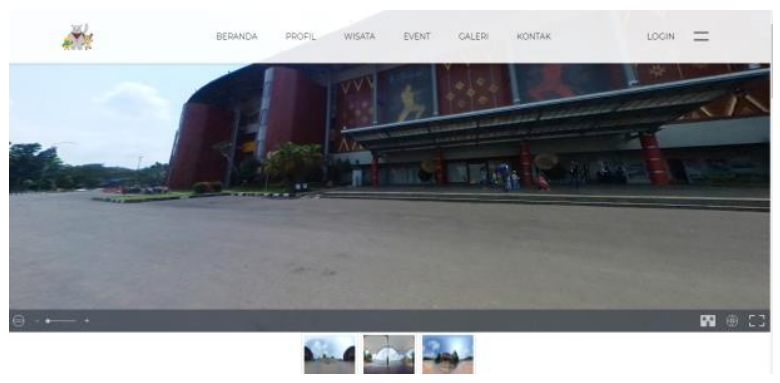

Gbr 7. Fitur untuk melihat foto-foto objek wisata melalui website

Tidak hanya melalui telepon genggam, Pada sistem informasi objek wisata ini juga menyediakan fitur untuk melihat foto-foto objek wisata melalui website. Hal ini ditunjukkan pada gambar 7 diatas, dimana pengguna dapat melihat beberapa gambar objek wisata.

Selain dapat melihat foto-foto objek wisata, pengunjung juga dapat memberikan rating penilaian dan memberikan komentar terhadap masing-masing objek wisata, hal tersebut dapat dilihat pada gambar 8 dibawah ini.

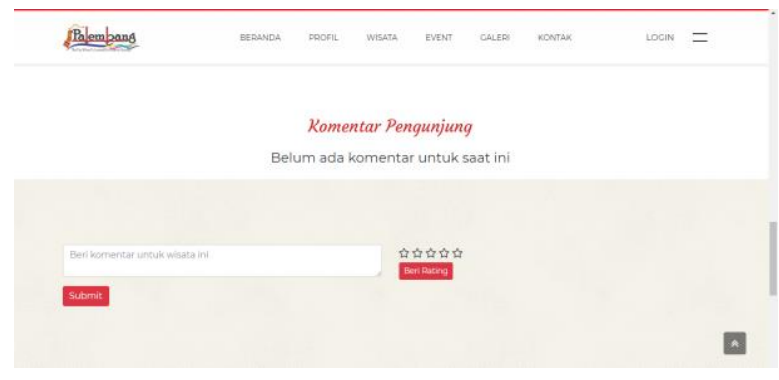

Gbr 8. Halaman rating penilaian dan komentar terhadap masingmasing objek wisata

\section{KESIMPULAN}

Berdasarkan hasil penelitian diatas dapat disimpulkan bahwa Virtual Reality Photography dapat memberikan suatu dampak yang baik. Dimana dengan adanya suatu teknologi ini, wisatawan secara interaktif mampu menimati suasana objek wisata tanpa harus datang terlebih dahulu ke tujuan. Kondisi objek wisata dihadirkan dalam bentuk visual yang jelas berbeda. Foto $360^{\circ}$ memiliki sudut pandang objek yang baik bagi pengguna dalam user experience. Sistem Informasi dengan bantuan Virtual Reality Photography ini akan diakses mudah pada suatu platfoam website. Sebab dengan kemajuan teknologi sekarang khususnya internet, ini merupakan suatu modal awal untuk penyebaran informasi yang maksimal. 
Untuk penelitian kedepan, penerapan teknologi Augmented Reality mungkin dapat menjadi media penyebaran informasi lainnya yang berkaitan dengan objek wisata, selain hal tersebut, penambahan audio akan menambah sensasi nyata bagi para pengunjung

Page | 73 objek wisata.

\section{REFERENSI}

[1] N. Isnaini and R. C. Irjayana.Aplikasi Berbasis Virtual Reality Dengan Photo Sphere dan Video Untuk Memperkenalkan Taman-Taman Di Kota Bandung. ISSN 2442-5826, vol. 2 ; 2016

[2] Wulur, H. W., Sugiarso, B., \& Sentinuwo, S. Aplikasi Virtual tour Tempat Wisata Alam di Sulawesi Utara. ISSN : 23018364, 6. ; 2015

[3] Highton, S. Virtual Reality Photography. In Virtual Reality Photography ; 2010

[4] A. Fahruddin and Y. Fitrianto.Virtual Reality Photography Untuk Media Promosi Online Objek Wisata Curug Tujuh Bidadari.19790414, vol. 1, p. 5 ;2015.

[5] Putra, P. Perancangan sistem pengelolaan sasaran kinerja pegawai (studi kasus: Fakultas Ilmu Komputer Universitas Sriwijaya, KNTIA 2017 Vol 4, p. D-202 - D-206, 2017. 